\title{
The effects of social media use and school culture on students learning outcomes junior high school 01 of kisam ilir sub-district
}

\author{
Hiri Yanto ${ }^{1}$, Yassir Arafat ${ }^{2}$, Alhadi Yan ${ }^{3}$ \\ ${ }^{1}$ SDN 01 Kisam Ilir \\ ${ }^{2}$ Universitas PGRI Palembang
}

\begin{tabular}{|c|c|}
\hline Article Info & ABSTRACT \\
\hline Article history: & \multirow{9}{*}{$\begin{array}{l}\text { This research is motivated by conditions among teachers. frequently use social } \\
\text { media. The research objective was to determine the effect of using social media } \\
\text { and school culture on student learning outcomes at Junior High School } 01 \\
\text { Kisam Ilir, Muaradua Kisam District. This research uses quantitative methods. } \\
\text { The population is } 172 \text { people and the research sample is } 90 \text { respondents. Data } \\
\text { collection uses questionnaires and documentation of student learning } \\
\text { outcomes which are then tested using the SPSS version } 2.5 \text { program } \\
\text { Hypothesis testing at the } 5 \% \text { significance level using the t-test, the conclusion } \\
\text { of this study H1 is rejected, this shows that there is no influence between } \\
\text { variable X } 1 \text { on variable Y. For H } 2 \text { is accepted, it shows that there is an } \\
\text { influence between variable X } 2 \text { and variable Y by } 97 \% \text {. To test the effect of } \\
\text { variables X } 1 \text { and X } 2 \text { on Y simultaneously, the F test is used which results in } \\
\text { H3 are rejected. The implication of this research is to cultivate social media in } \\
\text { the school environment to support learning achievement.. }\end{array}$} \\
\hline Received Jul $14^{\text {th }}, 2021$ & \\
\hline Revised Aug $18^{\text {th }}, 2021$ & \\
\hline Accepted Aug 30 ${ }^{\text {th }}, 2021$ & \\
\hline Keyword: & \\
\hline Social media & \\
\hline School culture & \\
\hline Learning outcomes & \\
\hline SPSS & \\
\hline
\end{tabular}

(C) 2021 The Authors. Published by IICET.

This is an open access article under the CC BY-NC-SA license (https://creativecommons.org/licenses/by-nc-sa/4.0

\section{Corresponding Author:}

Hiri Yanto

SDN 01 Kisam Ilir

Email: hiriyanto78@gmail.com

\section{Introduction}

The media that appeared for the first time were TV, radio, VCD, etc. which were categorized as old media. Although this old media has also experienced technological developments, for example, LED Screen TVs that adapt to today's themes. However, new media have emerged which are widely used by humans around the world, although this old media cannot be abandoned, this is because scientific advances are always followed by technological advances. This is proven by the many inventions in the field of technology to meet the needs of human life in carrying out various daily activities [1]

Technological advances are indeed very beneficial for humans because they can help make difficult jobs easy, such as the internet which is a new medium. Many people are increasingly integrated with this sophisticated program, this is because computer equipment, both hardware and software. Research results from the collaboration between the Indonesian Internet Service Providers Association and the Center for Communication Studies at the University of Indonesia show that the growth of internet use in Indonesia continues to increase. In 2012, internet users in Indonesia were 24.23\%. Meanwhile, a survey in 2014 showed that the penetration of internet users in Indonesia was 34.9\% [2] 
The increase in smartphone users implies that users are increasingly active in building social networks or social media. Social media is an online media, where users can easily participate, share, including Twitter, line, Facebook, Skype, Instagram, YouTube and others [3]

The researchers' observations of the conditions encountered by the use of social media both among educators and among students, this seems to have become an unwritten habit or culture. Whether this is done in normal circumstances means that it is used in a distance teaching system or a distance education system. In general, people in the school environment play a role in developing social media.

\section{Method}

This research method, quantitative can also be interpreted as a research method based on the philosophy of positivism, used to research on certain populations or samples, data collection using research instruments, quantitative / statistical data analysis, with the aim of testing predetermined hypotheses.

\section{Population}

Table 1.population

\begin{tabular}{lll}
\hline No. & population & total \\
\hline 1. & PNS Teacher / TU & 40 people \\
\hline 2. & Non PNS Teacher / TU & 12 people \\
\hline 3. & Students & 150 people \\
\hline & total & 202 people \\
\hline
\end{tabular}

\section{Sample}

\begin{tabular}{lll}
\hline & & Table.2.sample \\
\hline No. & Sample & total \\
\hline 1. & PNS Teacher / TU & 36 people \\
\hline 2. & Non PNS Teacher / TU & 9 people \\
\hline 3. & Students & 45 people \\
\hline & total & 90 people \\
\hline
\end{tabular}

\section{Data analysis techniques}

The result stage of data processing will be interpreted in the form of analysis to build a conclusion in response to the research objectives. This analysis will be tested by the SPSS program to prove the research hypothesis is accepted or rejected.

\section{Hypothesis}

The hypotheses of this study are: (1) Accepted if there is an influence of social media on student learning outcomes, (2) Accepted if there is an influence of school culture on student learning outcomes, (3.) Accepted if there is an influence of social media and school culture on student learning outcomes .

\section{Results and Discussions}

\section{Description of data use of social media}

The variable use of social media in research at SMP 01, Kisam Ilir Sub-District, OKU Selatan Regency, South Sumatra Province was measured using a questionnaire with a Likert scale consisting of 34 statement items. Social media use score scores ranged from 34 to 170.

Table.3. description of social media usage data

\begin{tabular}{ccccc}
\hline No. & Interval class & Frequency & Percentage & Category \\
\hline 1. & $157-166$ & 10 & $22.22 \%$ & Very Agree \\
\hline 2. & $146-156$ & 13 & $28.89 \%$ & Agree \\
\hline 3. & $135-145$ & 12 & $26.67 \%$ & Middle \\
\hline 4. & $124-134$ & 4 & $8.88 \%$ & Not agree \\
\hline 5. & $114-123$ & 2 & $4.44 \%$ & Very not \\
\hline
\end{tabular}




\section{Description of school culture data.}

The school culture variable in the research at SMP 01, Kisam Ilir Sub-District, OKU Selatan Regency, South Sumatra Province was measured using a questionnaire with a Likert scale consisting of 22 statement items. The school culture score scores ranged from 22 to 110.

Table.4. description of school culture data

\begin{tabular}{ccccc}
\hline No. & Interval class & Frequency & Percentage & Category \\
\hline 1. & $100-107$ & 16 & $35.56, \%$ & Very Agree \\
\hline 2. & $93-99$ & 14 & $31.11 \%$ & Agree \\
\hline 3. & $86-92$ & 5 & $11.11 \%$ & Middle \\
\hline 4. & $79-85$ & 6 & $13.33 \%$ & Not agree \\
\hline 5. & $72-78$ & 4 & $8.89 \%$ & Very not \\
\hline
\end{tabular}

\section{Description of student learning outcomes data}

The learning outcome variable in research at SMP 01, Kisam Ilir Sub-District, OKU Selatan Regency, South Sumatra Province was measured using documentation of grade 9 report card leger scores.The learning outcomes of these students are conditioned by the learning outcomes of the odd semester of the 2020/2021 school year, as for the number of students in grade 9 at Junior High School 01 Kisam Ilir is 64 people.

Table. 5. description of student learning outcomes

\begin{tabular}{ccccc}
\hline No. & Interval class & Frequency & Percentage & Category \\
\hline 1. & $806-844$ & 10 & $22.22, \%$ & verygood \\
\hline 2. & $771-805$ & 10 & $22.22, \%$ & good \\
\hline 3. & $733-770$ & 16 & $35.56 \%$ & middle \\
\hline 4. & $695-732$ & 6 & $13.33 \%$ & bad \\
\hline 5. & $657-694$ & 3 & $6.67 \%$ & Very bad \\
\hline
\end{tabular}

\section{Test the normality of variable $X 1$ against variable $Y$}

then it can be explained that results One-Sample Kolmogorov-Smirnov Teston the normality test, it shows that the Asymp.Sig. (2-tailed) $0.200>0.05$. Therefore, it can be concluded that data on the use of social media and learning outcomes are stated to be normally distributed

\section{Test for normality of variable X2 with variable $Y$}

then it can be explained that results One-Sample Kolmogorov-Smirnov Teston the normality test, it shows that the Asymp.Sig. (2-tailed) 0.200> 0.05. Therefore, it can be concluded that data on the use of social media and learning outcomes are stated to be normally distributed

\section{Test the linearity of variable $X 1$ against variable $Y$}

The result of the linearity test in the Anova Table shows that the value of Deviation from Linearity is $0.252>0.05$, therefore it can be concluded that the variable use of social media has a linear relationship with learning outcome variables.

\section{Linearity test of variable $X 2$ with variable $Y$}

Result The linearity test in the Anova Table shows that the value of Deviation from Linearity is $0.252>$ 0.05 , therefore it can be concluded that the school culture variable has a linear relationship with the learning outcome variable.

Hypothesis testing 1 (H1) 
Hypothesis 1 will be accepted if there is an influence of social media on student learning outcomes at SMP 01, Kisam Ilir Sub-District, OKU Selatan Regency, provided that the significance value is $<0.05$, and tcount $>$ t table

Table 6. Hypothesis 1

\begin{tabular}{|c|c|c|c|c|c|c|}
\hline \multicolumn{7}{|c|}{ Coefficients ${ }^{\mathrm{a}}$} \\
\hline & \multirow[b]{2}{*}{ Model } & \multicolumn{2}{|c|}{$\begin{array}{l}\text { Unstandardized } \\
\text { Coefficients }\end{array}$} & \multirow{2}{*}{$\begin{array}{c}\text { Standardized } \\
\text { Coefficients } \\
\text { Beta } \\
\end{array}$} & \multirow[b]{2}{*}{ t } & \multirow[b]{2}{*}{ Sig. } \\
\hline & & $\mathrm{B}$ & Std. Error & & & \\
\hline \multirow[t]{2}{*}{1} & (Constant) & 867.604 & 74.677 & & 11.618 & .000 \\
\hline & Penga.Medsos & -698 & .507 & -.205 & -1.377 & .176 \\
\hline
\end{tabular}

It is known from the picture that the significance value for the effect of variable $\mathrm{X} 1$ on variable $\mathrm{Y}$ is $0.175>$ 0.05 and tcount $1.377<$ ttable 2.01808, thus it can be concluded that $\mathrm{H} 1$ is rejected.

\section{Hypothesis testing 2 (H2)}

Hypothesis 2 will be accepted if there is an influence of school culture on student learning outcomes at SMP 01, Kisam Ilir Sub-District, OKU Selatan Regency, provided that the significance value is $<0.05$, and tcount> t table

Table 7. Hypothesis 2

\begin{tabular}{|c|c|c|c|c|c|c|}
\hline \multicolumn{7}{|c|}{ Coefficients $^{\mathrm{a}}$} \\
\hline & \multirow{3}{*}{ Model } & \multicolumn{2}{|c|}{ Unstandardized Coefficients } & \multirow{3}{*}{$\begin{array}{c}\begin{array}{c}\text { Standardized } \\
\text { Coefficients }\end{array} \\
\text { Beta } \\
\end{array}$} & \multirow{3}{*}{$t$} & \multirow{3}{*}{ Sig. } \\
\hline & & & & & & \\
\hline & & $B$ & Std. Error & & & \\
\hline \multirow[t]{2}{*}{1} & (Constant) & 889.969 & 58.594 & & 15.189 & .000 \\
\hline & Budaxa Sekolah & -1.332 & .622 & -311 & -2.142 & .038 \\
\hline
\end{tabular}

a. DependentVariable: Hasil belajar

It is known from Figure 5 that the significance value for the effect of variable $\mathrm{X} 2$ on variable $\mathrm{Y}$ is 0.038 $<0.05$ and tcount $2.142>$ ttable 2..01808, thus it can be concluded that $\mathrm{H} 2$ is accepted.,

\section{Hypothesis testing $3(\mathrm{H} 3)$}

Hypothesis 3 will be accepted if there is a simultaneous influence of the use of social media and school culture on student learning outcomes at SMP 01, Kisam Ilir Sub-District, OKU Selatan Regency with the condition that if the significance value $<0.05$, and $\mathrm{F}$ count $>$ Ftable

Table 8. Hypothesis 3

\begin{tabular}{|c|c|c|c|c|c|c|}
\hline \multicolumn{7}{|c|}{ ANOVAa } \\
\hline & Model & Sum of Squares & df & $\begin{array}{c}\text { Mean } \\
\text { Square }\end{array}$ & $\mathrm{F}$ & Sig. \\
\hline \multirow[t]{3}{*}{1} & Regression & 8166.999 & 2 & 4083.499 & 2.267 & $.116^{b}$ \\
\hline & Residual & 75651.579 & 42 & 1801.228 & & \\
\hline & Total & 83818.578 & 44 & & & \\
\hline \multicolumn{7}{|c|}{ a. Dependent Variable: HasilBelajar } \\
\hline
\end{tabular}

\section{The influence of social media use on learning outcomes}

This research is in line with the research conducted [4], Social Media Users and their Implications in terms of the perspective of Applied Social Psychology that there is no effect of the use of social media by teachers on student learning outcomes. Nurfitri, 2017)

\section{The influence of school culture on learning outcomes}

This research is in line with the research conducted [5], there is a significant influence of school culture on the learning achievement of grade VII students at SMP Negeri 2 Kota Probolinggo. 
(Christiani, 2016)

\section{The influence of the use of social media and school culture on learning outcomes}

The results of research that are different from the research conducted show that the e-learning system can be developed with social media in collaboration with several free web services such as Google Drive and Google Form. From the research conducted, it was found that 75\% influence on learning outcomes [6]

\section{Conclusions}

From this research, the conclusions are: (1) there is no effectthe use of social media among teachers on learning outcomes student learning outcomes of SMP 01, Kisam Ilir Sub-District, OKU Selatan Regency, (2) Budaya school on learning outcomes students of SMP 01, Kisam Ilir Sub-District, OKU Selatan Regency, (3)There is no joint influence - the use of social media among teachers - teachers with school culture on student learning outcomes of SMP 01, Kisam Ilir Sub-District, OKU Selatan Regency.

\section{References}

Adinugraha, HA, \& Kartikawati, NK (2012). Variations in morphology and nutritional content of breadfruit. Vana Seeds, 13 (2), 99-106.

Ariansyah, K., \& Ariyanti, S. (2017). The linkage analysis of telecommunication sector in the Indonesian economy in the mobile broadband era. Paper presented at the 2017 International Conference on Broadband Communication, Wireless Sensors and Powering (BCWSP).

Fahmi, AB (2013). Digesting social networking sites: Elex Media Komputindo.

Mulawarman, M., \& Nurfitri, AD (2017). Social Media User Behavior and Its Implications Viewed from the Perspective of Applied Social Psychology. Psychology Bulletin, 25 (1), 36-44.

Christiani. (2016). The influence of school culture and parental support on the learning achievement of social studies subjects in grade VII students at SMP Negeri 2 Probolinggo City. Journal of Social Studies Education and Research, 10 (1), 76-89.

Setiawan, D., Lestari, S., Putra, DS, \& Azmi, M. (2018). Utilization of Social Media to Build an E-Learning System at SMKN 1 Gunung Talang. INVOTEK: Journal of Vocational and Technology Innovation, 18 (1), 7-12. 